\title{
Liberation Songs: Music and the Cultural Memory of the Dutch Summer of 1945
}

\author{
Frank Mehring ${ }^{1}$
}

Photographs of victory and liberation of 1945 have entered the collective memory of contemporary viewers. In the United States, the iconic snapshot of the homecoming sailor kissing a nurse at Times Square in New York at V-J Day comes to mind, or: the liberation of Paris with crowds of French patriots lining the Champs Élysées to view Allied tanks and half-tracks passing through the Arc de Triomphe on 25 August 1944, the flag raising by Soviets over the Berlin Reichstag during the Battle of Berlin on 2 May, the liberation of concentrations camps in Auschwitz, Dachau or Buchenwald (by the us Third Army in April 1945), as well as photos of civilians greeting home-coming soldiers and the liberators of the Allied Forces. In the Netherlands, the picture of a Canadian Seaforth Highlander on a motorbike with two laughing girls on the backseat on the Amstellaan in Amsterdam (after the war the name of this street was changed to Vrijheidslaan/Freedom Lane) became one of the most popular images of the liberation. These scenes have entered the Dutch collective memory of the liberation and have been remediated in newspapers, magazines, documentaries, feature films, on social media platforms and innumerable Internet sites. I recently came across a remarkable image from the city of Nijmegen, which was liberated during Operation Market Garden in September 1944 (see fig. 1). We see people gather in front of a large brick building, singing and dancing. The photo was taken the following year on that memorable 5 May when the liberation of the Netherlands became official.

The feeling of being free again becomes visible in seemingly spontaneous, improvised performances. A piano has been pulled from a nearby house to the space in front of the Nutsschool at Hertogplein. The piano player sings and flirts with a woman standing next to him. Children sit in a church alcove slightly above the piano observing with many other bystanders the lively scene at the public

1 I would like to thank the following persons for their support in tracing the sheet music, photos, and for their inspiring suggestions: Rense Havinga from the National Liberation Museum Groesbeek 1944-45, American collector of Dutch ww II sheet music Hugo Keesing, and pianist Jens Barnieck for helping to make the music resound again.

(C) FRANK MEHRING, 2018 | DOI 10.1163/9789004292017_009

This is an open access chapter distributed under the terms of the prevailing CC-BY-NC License at the time of publication. 


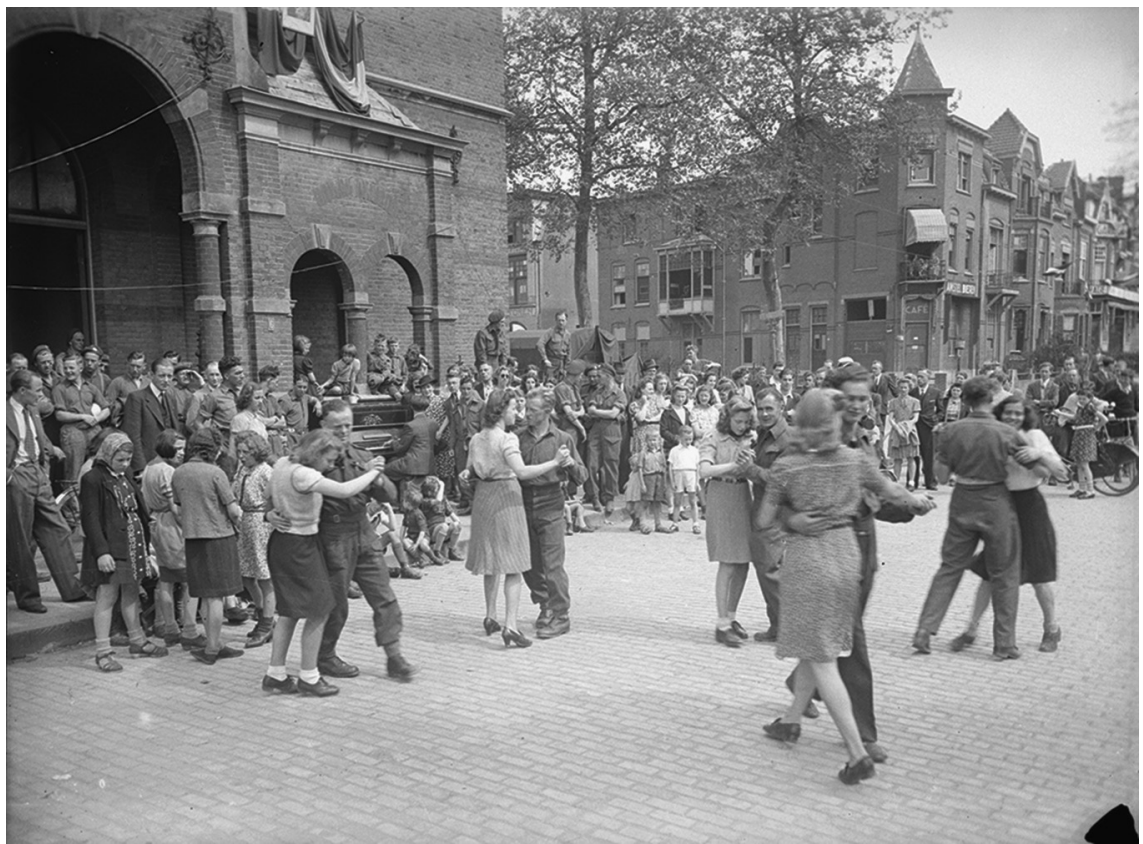

FIGURE 1 People dancing on Liberation Day on Hertogplein in front of the local school (Nutsschool) between Gerard Noodtstraat and Van der Brugghenstraat on 5 May 1945. FOTOCOLLECTIE REGIONAAL ARCHIEF NIJMEGEN.

place at the intersection of Gerard Noodtstraat and Van der Brugghenstraat in downtown Nijmegen: young men and women dance with each other celebrating the end of the war. What is expressed here are gratitude for the new-won freedom from occupation, a vital approach to deal with loss and the destruction surrounding the scene. ${ }^{2}$ However, the image remains silent. The question inherent in the photo is: what kind of soundtrack accompanies the scene? Could it be a Duke Ellington number? One of the latest swing, jive, foxtrot, or jitterbug dancing hits? Or perhaps something completely different, unexpected?

Historians have been surprisingly quiet about the sounds and soundtrack of history. In retrospect, the sounding signature for the Dutch liberation has become American jazz, in particular swing music and the close harmonies associated with the Andrews Sisters, as today's annual performances on 5 May (Liberation Day) in major cities such as Amsterdam, Arnhem, Den Haag, Nijmegen, Rotterdam, or Utrecht testify. Much of the original documentary

2 In the case of this image, ruins are carefully kept outside of the photographic frame. The building we see is intact while the area behind where the photographer stands has been destroyed in an allegedly mistaken bombing by us forces in February 1944. 
film material, however, is silent. In most cases, we do not have authentic audio recordings to accompany those familiar moving images of people singing and dancing-images that have been endlessly recycled in documentaries and news clips about the liberation. Rather, a commentator and pre-recorded music are often added in postproduction in the sound studio. Most often, we get to hear music linked to jazz and swing with the sound of American big bands. The trailer of the DVD Nederland Bevrijd: Einde 2de Wereldoorlog offers a paradigmatic example: The scenes of cheering Dutch citizens and Allied liberators celebrating in public urban places are underscored with a recording of Glenn Miller's In the Mood (1939). This link between liberation and jazz has become so popular that it resembles a cliché. If we want to know more about the actual soundtrack of liberation heard on the streets of 1945, we have to take into consideration the history of media, its peculiarities, practices, and limitations.

Since a large number of recordings is available to fill the empty soundtrack of silent images, American jazz music represents a persuasive musical source to add to clips of the liberation. The academic discussion on the influential power of a reference culture such as that of the United States suggests that the "interplay of political and economic supremacy with the 'soft power' of cultural attraction and reputation plays a crucial role in how certain cultures establish guiding standards for other cultures."3 One might ask: How American is the soundtrack of liberation? What hitherto untapped sources can we activate in order to find new answers regarding what kind of music accompanied the liberation on the streets and places of Dutch cities? Could it be that the history of the soundtrack of liberation has not yet been written?

The medium of music represents a "pioneering force" of crossing boundaries on cultural, ethnic, racial, and national levels (Raussert 13). Critics such as Wilfried Raussert and Reinhold Wagnleitner argue that music more than any other medium travels easily across borders, language barriers, and creates new cultural contact zones. ${ }^{4}$ During and after the liberation of Europe by the Allied forces, popular music and jazz played a crucial role as

3 This quote is taken from a 2014 conference at the University of Utrecht on Reference Cultures and Imagined Empires in Western History: Global Perspectives, 1815-200o (11-13 June 2014) where I presented an earlier version of this text. http://translantis.wp.hum.uu.nl/ conferences/2014-conference/

4 In addition to Raussert's Travelling Sounds, see also Wagnleitner Coca-Colonization and the Cold War, which traces forms of Americanization and self-Americanization putting music and radio in correspondence with advertising, comics, literature, education, theater, and fashion. Alfred Hornung and Rüdiger Kunow suggested that in the field of literature a shift of attention away from representations of the global towards what they call "culturally informed imaginings [...] of its effects" (197) might offer new insights into transnational networkings, 
a sounding signifier of new beginnings, producing a shared lingua franca which shapes our cultural memory. Building on the conviction, which Jacques Attali put forth in his work Noise: The Political Economy of Music, that music "is a way of perceiving the world" and a "tool of understanding" (4), I will ask: How did music transform the imagery of destruction, despair, and hope into a new emotional landscape? How can we critically analyze, map, and evaluate the nexus between sights, sites, and sounds of memory? How can we trace processes of cultural flows (William Uricchio) and (re) mediation (Jay David Bolter, Richard Grusin) in the musical culture of the liberators and the liberated nations? And to what extent does our cultural memory of music deviate from the experiential memory (in the sense of Aleida Assmann), namely the sound of the songs performed and heard in 1945 ? I would like to offer a triangular perspective on liberation songs combining the United States (as a reference culture) with the bordering countries of the Netherlands and Germany in order to analyze instances of cultural contact, transfer, and contested memories of liberation. The soundtrack of liberation encoded in the so-called liberation sheet music with elaborate cover designs, multilingual lyrics, and references to novel dances offers a new opportunity to approach the politics and cultures of liberation from a performative perspective.

\section{Sound Senses}

I borrow the term "soundtrack" from the medium of film. A film's sound world consists of spoken language, musical compositions, and sound effects. The soundscape theoretician R. Murray Schafer describes the general notion of "sound" as the "sonic universe" (95) — the totality of sounds produced by anybody and anything. My focus, however, lies with an exclusive rather than an inclusive definition of music. While the influential avant-garde composer John Cage argued that our traditional conception of music is too narrow and that "music is sounds, sounds around us whether we're in or out of concert halls," I am interested in the kind of songs and their musical performances which emerged at the end of the war and during the "magical summer of liberation"

cultural mobility, and diaspora. This approach can also be made useful for understanding the soundtrack of liberation.

5 I have traced Cage's inclusive concept of music as "organization of sounds" to Thoreau's observations regarding unpremeditated sounds in his early diaries. See Mehring, Sphere Melodies, 123-26. 
in 1945. But how can we find out what kind of music was actually played and heard at the time of liberation?

The unique collection of sheet music in the archive of the National Liberation Museum in Groesbeek offers a key to the soundtrack of the otherwise silent photos depicting dancing people in the summer of 1945. It reminds us that there was a genre called "Bevrijdingsliederen"-liberation songs. ${ }^{6}$ A photo of an advertisement in the front window of an Amsterdam music shop suggests that liberation songs were in high demand in 1945 . Underneath the headline "Bevrijdingsliederen" in capital letters, the expression "alhier verkrijgbaar" with a large exclamation mark (most likely in the color orange, the photo, alas, is only in black and white) indicates a sense of urgency and desire: Yes, we do have liberation songs available here! The collection offers a fascinating opportunity to explore, describe, and hear the soundtrack of liberation. With these musical notes and lyrics captured on paper, we may get closer to answering the question of what kind of music was played, what kind of songs were sung, and what kind of dances were performed in the summer of 1945. Surprisingly, apart from exceptions such as Trees heeft een Canadees, Als Op Het Leidscheplein de Lichtjes weer eens Branden Gaan, or Lili Marleen few people remember songs such as Vrij is Nederland, v-e Day, Herrijzend Nederland, Da-ag, Da-ag, Da-ag How I like this way to say "Hello," Rotterdam Ahoy, Little Holland Girl, Eens zal de Wereld Zingen, Rood Wit Blauw, The Tommy Song, Tulips Bloom in Holland Once Again, Weet je Wat een Zoentje is? Een Zoentje is "A Little Kiss," or De "StenGun Walk." This remarkable gap in the history of liberation needs explaining.

6 Hugo Keesing, retired adjunct associate professor of Psychology and American Studies at the University of Maryland, donated his collection of Dutch sheet music, which dealt in some form or another with the experience of liberation. Keesing was born in Den Haag and emigrated in $195^{1}$ with his parents to the Us. He had been interested in the political function of music during the Vietnam War as well as World War II. His dissertation Youth in Transition: A Content Analysis of Two Decades of Popular Music from 1972 is an early example of critical academic analysis of the kind of popular music which then was considered "an unpleasant manifestation of youthful rebellion, including a lack of good musical taste, which most teenagers would inevitably outgrow" (Keesing 2). His Dutch sheet music collection of almost 300 songs provides a unique perspective on the soundtrack of liberation combining elaborate cover designs, musical scores and in many cases multilingual lyrics. Astonishingly, hardly any of the songs are familiar to Dutch audiences apart from exceptions such as Trees heeft een Canadees or Lili Marleen. This is a curious surprise, which demands explanation. 
Thus, another unexpected question arises: why have most of these songs, which formed the soundtrack of liberation, been more or less forgotten? ${ }^{7}$

Before we have a close look at the scores, it is crucial to clarify the premises of my project on the "soundtrack of liberation" and define the terms. Since nineteenth-century lantern shows and the origins of film in the 189os, music has been played in order to both enhance the emotional impact and to overcome the gap between the technical projection of a fictitious world and the illusion of the real. However, the theme of liberation, music, and songs goes back further in time. Indeed, they feature prominently in the oldest parts of the Bible. ${ }^{8}$ For example, when God led the Israelites through the desert, parted the sea and a fire in the sky showed the way to the land of freedom-IsraelMoses sings the song of liberation and deliverance: "Then sang Moses and the children of Israel this song unto the LORD, and spake, saying, I will sing unto the LORD, for he hath triumphed gloriously: the horse and his rider hath he thrown into the sea. The LORD is my strength and song, and he is become my salvation" (Exodus 2, chapter 15, King James Version).

If we want to understand the function of music in the socio-cultural and political context of oppression and liberation, we have to take into account the different functions which Attali ascribed to music: first, in a ritualistic context it can "make people forget," in particular the experience of extreme violence; second, in a commercial context it can "make people believe in the harmony of the word;" third, in a constellation of capitalism and mass production it can serve to silence and censor (19). Regarding the concrete manifestation of film music, Siegfried Kracauer's description is particularly helpful. He argued that music provided a "meaningful continuity in time" thus helping the audience to perceive "structural patterns where there were none before" (quoted in Cooke 12). This observation is crucial if we look at the effects music has on the perception of liberation. Concerning the function of music as a kind of glue between potentially confusing confrontations, between different visual shots, angles, narratives, and jump cuts in the editing, a soundtrack fulfills a compensatory function. In his work on The Aesthetics and Psychology of the Cinema, the influential French film theorist Jean Mitry explains the connection between visual disruption and the function of our mind to create new continuities. Music plays an important in this process: "it is all too apparent that the editing of a series of fixed shots establishes a feeling of continuity but is unable, unlike moving shots, to create the sensation of the continuous, since this sensation

7 From 2 May to 30 September 2007, the Verzetsmuseum in Amsterdam offered an exhibition called "Bevrijdingsmuziek" featuring a selection of covers and scores from 1944 and 1945.

8 I am grateful for Jens Barnieck tracing these Biblical roots of liberation songs. 
is reconstructed intellectually and not perceived as such-which means that reality appears as though it were an idea or memory; or, to put it another way, it appears restructured" (162). Memory, too, is restructured through music. Music allows us to create a reasonable narrative out of disjointed sensations such as war, destruction, friendly fire, and liberation. As far as liberation music is concerned, I would like to distinguish between four different types:

1. Liberation songs that have formed the basis of western culture in the Bible and poetry - first in aural culture and later in print. More recent examples from the transatlantic world include poetry from the U.S. Wars of Independence, the French Revolution, the German Wars of Liberation, the two World Wars, etc. Poems of earlier periods often re appear later in the form of songs, such as the patriotic poetry of Theodor Körner from the German Wars of Liberation which reappeared as songs in World War I, or poetry by Walt Whitman from the American Civil War which reappeared in World War II.

2. Musical soundtracks based on the work of film music composers for feature films or documentary films. Before the invention of sound film, parts of classical music were often used to frame sequences of "liberation," as for instance Wagner's "Ride of the Valkyries" in D.W. Griffith's patriotic, albeit racist work on the history of the United States Birth of a Nation (1915). For the period from the end of World War II until today, musical soundtracks play a decisive role to underscore the experience of war and liberation in films ranging from compositions by Gail Kubik for The Memphis Belle (1944), Hugo Friedhofer for The Best Years of our Lives (1946), Victor Young for Sands of Iwo Jima (1949) to Jerry Goldsmith for Patton (1970), John Williams for Saving Private Ryan (1996), and Alexandre Desplat for The Monuments Men (2014).

3. Concert music composed for socio-culturally and politically decisive moments in history ranging from the French Revolution, the American Revolution, the German Wars of Liberation, and the two World Wars, to the Vietnam War, the fall of the Berlin Wall in 1989 and the ensuing newly won freedom of Eastern European countries, and current global conflicts. For the final period of World War II and the early postwar years, examples include compositions such as Arturo Toscanini's Hymn to the United Nations, Dimitri Shostakovich's United Nations March (featured in the MGM war-time musical Thousands Cheer from 1943, a march for which the American composer and conductor Leopold Stokowski also created a symphonic transcription), Kurt Weill's United Nations Song as part of the song cycle Songs of 
the Free, or They are There by the so-called father of American music, Charles Ives, which expresses the notion of liberation and freedom in terms of classical and avant-garde music.

4. Gebrauchsmusik, a "music of use" created for a specific purpose as defined by Paul Hindemith, Ernst Krenek, and Kurt Weill. The GermanAmerican composer Weill, for example, wanted to liberate opera from its paralyzing prison of tradition. He saw in the use of new popular idioms such as jazz and contemporary themes such as The Lindbergh Flight (1929) across the Atlantic or the biting critique regarding life in big cities Rise and Fall of the City of Mahagonny (1930) an opportunity to invigorate the musical theater of the Weimar Republic. During World War II, he contributed arrangements of patriotic songs such as Battle Hymn of the Republic, Beat! Beat! Drums!, or The Star-Spangled Banner to the American war effort. In popular music from World War I and II, "music of use" refers to songs published as sheet music and performed by soldiers or civilians to celebrate the liberation and newly-won sense of freedom. They are composed, written, published, and performed for a specific time frame in a particular socio-cultural and political environment. Thus, they had a built-in expiration date, a kind of "best used before the end of liberation."

In the following sections, I would like to put my searchlight on the final category of Gebrauchsmusik. As a manifestation of the soundtrack of liberation, Dutch sheet music - which functioned to express the feeling of liberation, freedom, and hope for a better future-serves as a revealing case in point to complicate the all too easy explanation that the triumph of American (popular) culture in the Netherlands should be seen as a consequence of cultural imperialism.

\section{Sounding Intercultural Encounters}

The popular sheet music, which I refer to as the "soundtrack of liberation," has a strong expressive potential. The cover art, the lyrics, the music, and public performances collectively function as a means for self-expression and self-affirmation of Dutch citizens after the liberation. These audio-visual and textual products respond to the cultural encounters with one or several reference cultures of the liberators. The production and performance of sheet music allows for the articulation and representation of an imaginary of the past and future. I am using the term "imaginary" following Winfried Fluck's 
definition of the word as a concept to "describe the unstructured and decontextualized stream of images, associations, sensations, and feelings that constantly feed our cognition and interpretation of the world without having a tangible form of their own" (244). The key term "liberation" plays a central role in the European imagination from 1945 to the present. For example, the Liberation Route Europe, a multi-media project that was launched in 2013, offers a new multinational perspective on World War II by focusing on the shared experience of liberation and a newly won sense of freedom asking: How can we forge a common European denominator that builds on our common (media) memory of World War II and emphasizes positive elements such as freedom and liberation? ${ }^{9}$ What does this mean regarding the memory of the soundtrack of liberation? Is there a shared recollection of songs? ${ }^{10}$ If we put our searchlight on the short phase in which the sense of liberation was expressed in lyrics, songs, and music, we are able to trace the culture of liberation at a crucial moment shortly before, during, and immediately after the liberation of the Netherlands.

The performance culture of Dutch liberation songs is not based on exhibiting special skills, musical talents, bodily attractions, technological or

9 Aline Sierp argues that since the 199os the "common experience of repression, dictatorship and genocide [...] turned into a point of reference for the definition of the [European] Union's values and political goals" (115). In the new millennium, new initiatives such as the Liberation Route Europe have tried to shift the focus away from the experience of trauma and destruction.

In the case of the Dutch liberation, we need to keep in mind that the American forces did not play a crucial role in the liberation of the northern parts of the country. Nonetheless, the United States State Department made sure that the American intervention became particularly relevant in the Dutch national imagination and memory. The cultural diplomacy and soft powers of the Marshall Plan played an important role to enhance the U.s. contributions to the Dutch economic recovery and to a certain degree their role in the Dutch liberation. For example, the exhibition De Amerikaanse Droom in Nederland 1944-1969 in the Nederlands Openluchtmuseum (and the informative catalogue by Jan Donkers) shies away from questioning conflicting memories and taboos in favor of liberation in the immediate aftermath of the war called "Bevrijd en besmet" (liberated and infected”) with an emphasis on Marshall Plan help, images of liberation, Donald Duck, and the Wild West. Not surprisingly, as far as music is concerned, jazz figures most prominently. The exhibition even introduces the expression "second liberation" to describe the culture of the fifties with Hollywood, cars, jeans, and Rock ' $n$ ' Roll music. The images in the exhibition reveal a sense of complicity with the message of the Marshall Plan as the seal for the European Reconstruction Program with the American flag and shield or the Strength for the Free World emblem show. Far from creating a narrative of hegemonic Americanization, the exhibition on the American Dream and liberation is a paradigmatic example of self-Americanization. 
other sensational feats. Rather, it is a form of Gebrauchsmusik ("music of use") created for a specific national audience during the narrow time frame between the liberation beginning with the September 1944 offensive "Operation Market Garden" and the period surrounding the official liberation of the Netherlands and the capitulation of Nazi Germany in May 1945. During that time period, popular sheet music had not yet entered into competition with what would soon become the most important mediator of culture: the American movies and record industry. Before Dutch audiences could engage in the immediate experience of American sights, sounds, and fantasies and absorb their illusions of reality, popular sheet music offered a welcome means to celebrate and express feelings of joy, pride, and gratitude. The exuberant feeling of being free again was, in most cases, dominant despite the dire reality of destroyed cities, war casualties, torn families, and uncertainty regarding lost friends or family members. This short-lived period of exception, of first expecting to be liberated followed by the actual experience of being free again, created the magical feeling of the summer of 1945 . When it was over, the usefulness of most of the songs had expired. Thus, hardly any of them were recorded and entered the collective memory.

How can we describe the music, which filled the streets, bars, and public spaces? The blue print for the Dutch liberation songs are the American sheet music publications from the period after the 1910s when the cultural craze of jazz and later swing swept over Europe. These publications themselves built on the nineteenth-century popular sheet music, in particular those songs based on minstrel songs. The Dutch soundtrack of liberation was to a certain degree informed by the rich archive of World War I sheet music and the interwar years.

The World War I sheet music from the U.s. combined musical notes with lyrics and colorful designs, which formed a visual gateway into the song. The manifold themes can be categorized into songs which

1. celebrate the belief in American liberty with the colors of the flag and icons such as the Statue of Liberty

2. mediate the value of democracy

3. emphasize the need to fight for American core values

4. commemorate crucial battles at Verdun, in Flanders, or Berlin

5. identify and satirize the enemy

6. idealize the life of soldiers

7. express feelings of longing for loved ones.

In World War II, the media situation became more complex. Soldiers listened to the radio, watched films, played records, and enjoyed live 
performances. Nevertheless, sheet music continued to play a decisive role. The sheer number of songs published in the United States indicates that this nineteenth-century medium served its purpose of drumming up support, fostering a spirit of community among soldiers, stirring up patriotism, and ridiculing or stigmatizing the enemy. The themes, which I identified for the period between 1914 and 1918, continued to inform the productions of the 1940 os as is indicated by the selection of sheet music covers below with titles such as Remember Pearl Harbor, Old Glory: Star Spangled Rhythm, Marching and Singing, Der Fuehrer's Face, Ten Little Soldiers, We Did It Before, or Praise the Lord and Pass the Ammunition!!

The Dutch liberation songs embraced u.s. marketing strategies through elaborate cover art as a first means for potential buyers and performers to get an idea of what the song was about. What kind of music can we identify in the collection of Dutch liberation songs? There are five categories particularly relevant to express a new sense of freedom: hymns, love songs, marches, boogie-woogie and swing, and foxtrot songs. In the following section, I will concentrate on the analysis on the last three categories. ${ }^{11}$

\section{Marching Music Between Occupation and Freedom}

It might come as a surprise that the very musical genre that the National Socialists and the NSB (National-Socialist Movement in the Netherlands) identified as the genre suited best to transport authoritarian ideas and fascist aesthetics continued to be popular: marches. In song collections such as S.A. Liederbuch, Singendes Volk and Kameradschaft im Lied, as well as nonfiction books such as Joseph Müller-Blattau's Germanisches Erbe in Deutscher Tonkunst (with a preface by Heinrich Himmler) or Richard Eichenauer's Musik und Rasse, National Socialists recognized that marching music could help to de-individualize people, form them into a controllable mass, and manipulate them to embrace a specific political ideology. ${ }^{12}$ Youth groups often participated in ritualistic singing traditions and marches as a kind of paramilitary exercise.

11 A more comprehensive analysis of all the categories, including illustrations and musical examples, can be found in my book Soundtrack van de Bevrijding. Swingen, Zingen en Dansen op Weg naar Vrijheid (Nijmegen: Vantilt, 2015) with contributions by Anja Adriaans, Jens Barnieck, Rense Havinga and Hugo Keesing.

12 In addition to marching music, National Socialists emphasized the importance of folk songs for ideological purposes. See for example Thomas Phleps "Musik und Ideologie" (2002). 
In the Netherlands, the popular collection of marches and war songs, Zoo Singt de NSB (twintig Marsch- en Strijdliederen), paved the way for using music as a means to "educate" the young, and transform them into a uniform mass of soldiers. The motto "Du bist nichts, dein Volk ist alles" (you are nothing, your people is everything) translated well into the idea of marching uniformly in rows eliminating a sense of individuality. Since May 1940, formations of the Jeugdstorm, Nederlandsche Arbeidsdienst, and the Dutch ss marched through the streets while singing songs such as the Swarthemdendlied, Vrijheid en Recht, WA Marcheert, Voorwaarts, Stormsoldaat, or the Oostlandlied. ${ }^{13}$ The latter was sung by thousands of Dutch soldiers fighting at the Eastern front.

Music and striking cover art created an aesthetic unity, which found its powerful expression in the marching and singing in public spaces and during ritualistic festivals. Examples include the silhouetted rows of soldiers on the covers of Singend door alle Dietsche gouwen or Lied der Legionssoldaten (Opgedraagen aan wijlen sijne Luitenant Generaal H.A. Seyffardt). The combination of marching music and political topics strengthened a sense of unity among a certain group of people or soldiers. This kind of music should persuade, agitate, and overwhelm. ${ }^{14}$ When combined with certain uniforms, symbols, and color codes, the effect could be particularly striking. Certain key words and musical signature sounds set easily recognizable frames of reference. Key words included freedom, nation, flag, and fatherland. Important musical signatures were a marching beat and the typical fanfare-like rising fourth interval at the beginning. Why, however, would composers of liberation songs revert to the very musical genre that had become a blueprint for the occupation and for a traumatic experience of censorship, loss of cultural identity, and national humiliation?

Judging from the cover art and lyrics, marching music became an effective means of reasserting freedom and recovering what was lost. Songs such as We zijn weer Holland en we zijn weer vrij!, De Vrijheidsmars, Vredesmarsch, or Vry Nederland (Vryheidsmarsch) show how music can become a means of celebrating the end of oppression. Now the signs of the occupiers were replaced by the iconic Dutch lion unchained. On 5 May 1945, the front page of De Gelderlander newspaper featured a poem next to the image of Queen Wilhelmina, in which the metaphor of the Dutch lion had a similar function in poetry and musical cover art:

13 As Gerard Groenveld explains in Zo zong de $N S B$, these songs have been forgotten over the decades (200).

14 See in this context Hanns-Werner Heister's entry on political music in Die Musik in Geschichte und Gegenwart (1997). 
De Hollandsche leeuw hoeft, Van woede verbeten, Niet langer onmachtig Gekerkerd te zijn.
The Dutch lion, Pent up with anger, Need no longer be impotent And encaged.

The color orange pervaded public spaces as a national metaphor of freedom regained. This color code in combination with marching music strengthened the national identity of people. The importance of the color orange can even be traced in newspaper articles printed in orange after the liberation. ${ }^{15}$ At the same time, the references to Dutch history, language, and the country's proud and strong people helped to erase the five-year gap of humiliation and cultural colonization. Dutch marching music with themes of freedom, nationhood, and patriotism thus allowed the people to come to terms with the traumatic experience of occupation and war.

The return of Dutch marching music is closely tied to emotions triggered by sounds heard between 1940 and 1945 . One only has to think of the sound field of occupation in the streets of major Dutch cities. Apart from the howling of sirens during air attacks, the droning sounds of airplanes above the cities, the ear-shattering sounds of bombs crashing into houses in city centers, Dutch war diaries often refer to an uncanny kind of silence after the beginning of the occupation. In May 1940, there was hardly any traffic, buses did not run, taxis were unavailable. Due to the shortage of gas, doctors could not make visits to patients (except on bicycles). After October 1942, when all forms of musical performances were banned from the streets, Dutch citizens longed for the familiar tunes played by the popular street organs. In addition, church bells fell silent after they were molten into cannon and other military equipment. Anne Frank described in her famous diary that she lost her sense of time after the Westerkerk bell stopped telling the citizens of Amsterdam the time of the day. With the loss of bells came the silencing of carillon music. The sound of German troops singing their marching songs filled the silence. In Amsterdam alone, 14.000 German soldiers contributed to the sound field of the city with their language and music. Some described the singing of German soldiers and the NSB as terribly off-key. Studies of Dutch war diaries reveal that one of the psychological strategies of occupied citizens to cope with unwelcome foreign cultural politics was to either ignore sounds associated with occupation or to

15 Interview with Rense Havinga conducted for the MA paper "Liberation Songs" at Radboud University by Esther Adema, Litania de Graaf, and Rita Hynes in June 2014. 
categorize them as unpleasant. ${ }^{16}$ After 1944, one liberation song by Ar Colijn with a quick rhythm and catchy lyrics explicitly addressed the new sonic experience of hearing The Bells Now Ring Again, as the title of the song indicates. The chorus says:

The Bells now ring again.

We did not wait in vain,

The sun drove out the rain

The Nazis slain,

Let's elevate our voice,

Sing to the Tommy boys

Our songs of gratitude.

In cheery mood.

All nightmares are ended,

Suddenly just as the war intended:

Liberty!!!

Now shake hands,

With Americans,

In steady brotherhood,

And cheery mood.

We have to imagine a special sound field in 1945: the sounds of bells returning to destroyed city centers in combination with marches such as Wij zijn weer vrij! (Lied van Vrijheid en Vrede) with words by A.J. Driest and music by Hendrik van Beek presented in "gematigd Marschtempo met spontane voordracht" with a moderate marching tempo and spontaneous singing:

Wij zijn weer vrij!

Heft aan onz' jubel zangen.

$\mathrm{Nu}$ wij, verlost van slavernij,

Den vrede weer ontvangen.

Zoo moge dan die vrede

Ons hoeden voor hernieuwd geweld.

De vredes zonne stralen beschijnen

't eeuwig vredesveld.
We are free again!

Let us sing our jubilant songs.

Now that we, free from slavery,

Receive peace again.

So may that peace

Protect us from renewed violence.

The sunlight of peace shines

On the eternal field of peace.

16 Annelies Jacobs and Karin Bijsterveld speak in this context of "politics of sound" based on their analysis of Amsterdam diaries. See "Der Klang der Besatzungszeit: Amsterdam 1940 bis 1945" (2013). See also Annelies Jacobs's Het Geluid van Gisteren: Waarom Amsterdam Vroeger Ook Niet Stil Was (2013). 
The composer Hendrik van Beek notes that the final line of the chorus should be sung with great emphasis on melody and rhythm:
Zoo rijz' ons aller bede,
Thus rise all of our prayers,
Dat voortaan t'allen tij That from now on for all time
Op aarde heersche vreede
En Neerland blijve vrij!
On earth shall reign peace
And the Netherlands be free!

With a final fanfare on the rising basic chord of $\mathrm{C}$ major the march ends on a fortissimo celebrating music, freedom, and peace. The keywords "rise," "prayers," "peace," and "free" mentioned in this march are also present in most of the other compositions, which might be subsumed under the category freedom marches.

\section{Liberation Boogie-Woogie and Swing}

Contrary to the aesthetics of marching practiced by the National Socialists and the NSB, the African-American genre of boogie-woogie and in particular the emerging swing movement focused on individual expression of vitality through dance rather than paramilitary exercises accompanied by a steady beat. The mostly piano-based boogie-woogie, with its recognizable melodic bass lines and syncopated rhythms, became most popular in the 1930 and was picked up by swing bands such as Tommy Dorsey's and Glenn Miller's. In the Netherlands, the song Gee, I like this Boogey Woogey Swing from 1945 by Han Ninaber testifies to the function of music to overcome sadness and sorrow.

Heeft U weleens zorgen?

Last van rheumatiek ...?

Dan weet ik een middel

't middel heet muziek:

Speel voor mij een beetje dansmuziek.

Daar ben ik dol op,

Ja dat vind ik knal.
There is a brand new rhythm, ${ }^{17}$ Listen for a while. To the very popular Boogey woogey style.

Gee! I like that boogey woogey swing With boogey woogey Life is never blue. 
There is a slight difference of emphasis between the Dutch and English lyrics. The Dutch version contrasts more dramatically the experience of grief with the healing power of the boogie-woogie: "met wat Boogey Woogey 'Swing' muziek vind ik het leven lang nog niet zoo mal" (with this Boogey Boogey Woogey "Swing" music I find life is not all too bad). ${ }^{18}$

The National Socialists had responded to performances of AfricanAmerican musicians and music with roots in black culture with defamation. The Düsseldorf exhibition "Degenerate Art" (Entartete Kunst) from 1938 identified blues, boogie-woogie, and swing as poisonous infiltrations of socalled Aryan art. The Dutch version of the National-Socialist caricature of "Liberators" encouraged the viewer to read the Dutch Nazi paper Storm-ss. The cover identifies the United States as a racist robot out of control, covered in the hood of the Ku Klux Klan, with a torso of a cage in which an African-American couple dances a jitterbug, and legs made of bombs threatening to destroy iconic German cities. Musically, the references discredit the U.s. as a country holding a gun in one hand and a drumstick in the other, ready to produce the rhythm of destruction. Destruction also comes from the alleged weapons the American war machine holds in its hands: a sack of American dollars and a record, indicating the threat from the powerful connection between entertainment and capital. In awe of such an onslaught of "acoustic terror," the little figure in the foreground can hardly believe his ears, which have grown beyond reasonable proportions. The sign he is holding mocks the promise of the liberator: "De U.S.A. zullen de Europeesche Kultuur van den ondergang redden" (the U.S.A. will save European Culture from Destruction). ${ }^{19}$

18 Translation by F. Mehring.

19 The response to new American musical styles of African-American origin continued to be controversial in many European countries. For example, despite initial efforts to discard African-American music as primitive, immoral, and alien, the ввС program shifted towards a more positive image of jazz in 1943 due to its function to lift spirits in times of war. It is particularly striking that with the establishment of the American Forces Network in July 1943, such music "served as a catalyst for those worried about Americanization, which they regarded as a threat to the survival of a distinctly British culture" (Victory Through Harmony, 177). Even the German radio propaganda utilized jazz music to attract British and other soldiers, inserting propaganda messages in-between. Horst J.P. Bergmeier and Rainer E. Lotz have offered an overview of National-Socialist subversive radio programming and Goebbels' propaganda orchestra around the crooner Karl ("Charlie") Schwedler in Hitler's Airwaves: The Inside Story of Nazi Radio Broadcasting and Propaganda Swing (1997). 
The spreading of African-American music could hardly be containedneither in Germany, nor in the Netherlands. ${ }^{20}$ Before and during the Olympic Games in Berlin in 1936, the musical borders were already porous. The refined arrangements of orchestral dance music by the likes of Duke Ellington or Benny Goodman impressed German musicians, who immersed themselves in the African-American styles of swing, foxtrot, and boogie-woogie. The German bandleaders and musical followers of Ellington and Goodman were Teddy Stauffer and Kurt Widman. Thus, swing sounds emerged from German record stores, in movie houses showing American musicals, and dance parties featured swing from both sides of the Atlantic. Due to defamation of jazz and swing by the National Socialists, lyrics of "hot music" were often Germanized. For example, one of the earliest African-American success numbers, "Tiger Rag," became "Schwarzer Panther." Even National Socialists did not follow a clear line on how to approach African-American music between discrediting swing as "degenerate" or silently condoning it. The party response to swing can best be described as hypocritical. ${ }^{22}$ The individualistic emphasis on solo instruments, improvisation, and the African-American roots did not fit into the concept of music as a tool of propaganda for melting the individual into a uniform mass. Thus, the German swing movement with its creative, individualistic, and even anarchic attitude and with its own fashion code represents the first German youth subculture that defined its resistance to the status quo through music.

What Hans Dieter Schaefer described as a "split conscience" towards swing and similar strategies to undermine National-Socialist regulations can also be found in the Netherlands. Swing and boogie-woogie could be enjoyed only when hidden behind Dutch sounding titles. One of the best-known Dutch orchestras, The Ramblers, was formed in 1926 (see Swaart 233). It emerged in the wake of the European tours by the famous African-American clarinet player Sidney Bechet and Paul Whiteman-the self-acclaimed "King of Jazz"-and his swing

20 Walter van de Leur traced the history and reception of jazz music in the Netherlands by looking at the Dutch magazine Jazzwereld, which was published between 1931 and 1940. He explained that " $[\mathrm{t}]$ he purpose of both De Jazzwereld and the Nederlandse Hot Club ( $\mathrm{NHC}$ ) was to promote and defend jazz, to educate players, listeners and adversaries alike, to organize concerts, competitions, and lectures, to push radio stations to play more jazz, and to establish a network of like-minded jazz lovers" (unpaginated).

21 One of the earliest historians who described the function of jazz in German culture was Horst H. Lange in his overview Jazz in Deutschland. Die Deutsche Jazz-Chronik 19oo-1966 (1966).

22 Here, I follow Bernd Polster's conclusion regarding the fine line between discrediting and condoning swing music in the 193 os and 4os. See Swing Heil! Jazz im Nationalsozialismus (1989). 
orchestra. After 1933, The Ramblers with their jazz and swing program became influential via radio performances for VARA, the Vereeniging van Arbeiders Radio Amateurs. However, when the Departement van Volksvoorlichting en Kunsten passed the law "Verbod van negroide en negritische elementen in dans- en amusementsmuziek" (Law against black and "blackish" influences in dance and popular music), English-sounding band names were forbidden. The Ramblers changed their name emphasizing the role of their bandleader into Theo Uden Masman en zijn dansorkest (Theo Uden Masman and his Dance Orchestra).

In the collective consciousness of the Netherlands, the sound and music of the Ramblers is closely connected to the soundtrack of liberation. However, in the summer of 1945, The Ramblers did not perform a single song of their jazz and swing repertoire in the country. Since they had also played for the German Wehrmacht and the National-Socialist Nederlandsch Arbeidersfront, The Ramblers were banned from performing after the liberation. Under the leadership of drummer Kees Kranenburg the band went on tour in other countries. After the magical summer of 1945 was over, things calmed down. In January 1946, the ban was lifted and The Ramblers continued their success story.

The German term "Verniggerung" became part of a large-scale prohibition of African-American music in record stores or on radio channels during the war. African-American performers were banned from Germany and the occupied countries. This created a musical vacuum in the Netherlands as elsewhere, and explains the particular interest of music publishers and performers alike to gain access to sheet music. However, printed scores can only provide a limited understanding of what makes the musical genre of boogie-woogie and the use of improvisation so unique in live performances. Not surprisingly, early efforts of Dutch composers to utilize these novel genres produced an often awkward appropriation, not unlike, by the way, to the early efforts of experimenting with jazz by Ernst Krenek, Erwin Schulhoff, Paul Hindemith or Kurt Weill immediately after World War I. For example, the Dutch liberation song Ik kan niet swingen (I cannot swing) points to the gap between the desire to participate in the new musical dance sensation from the U.S. and the inability to do so shortly after the liberation. As a matter of fact, the song Ik kan niet swingen is composed as a foxtrot. As Duke Ellington would have said as early as 1932: "it don't mean a thing if it ain't got that swing":

k kom uit heel gegoede kringen, $\mathrm{k}$ kweek exotische seringen.

Ik zit vol betoveringen, maar helaas, ik kan niet swingen.
I come from very wealthy circles, I grow exotic flowers. I am full of enchantments, However, unfortunately, I cannot swing. 
The cultural opposition towards the music of the occupiers turned jazz into the soundtrack of the liberators for many. Syncopation, swing, blue notes, and improvisation became loaded with political associations. ${ }^{23}$ As Kees Wouters suggested, by objecting to jazz, Dutch people risked the stigma of siding with the former enemy: "[p]laying a Nat Gonellaw or a Benny Goodman record on a birthday party, one demonstrated that one was on the 'right' side" (507). The attitude towards jazz in the Netherlands would soon become more polarized. ${ }^{24}$ In 1945, Jack Bulterman recognized an opportunity to fashion himself into a musical mediator par excellence.

Among the most successful numbers of The Ramblers after 1945 was Bulterman's composition Bouncin' in Bavaria, which became a standard in big band repertoires..$^{25}$ The song gained recognition in many European countries. Bouncin' in Bavaria was considered the best song of a concert in Groningen in February 1950. In Great Britain, Bouncin' in Bavaria was one of the most requested songs (Morley 131). The American Forces Network in Munich used it as their signature tune for a radio show of the same name: "Bouncin' in Bavaria." An article in Nieuwsblad van het Noorden identified the song as a well-known AFN tune ("Bouncin' in Bavaria, de van de AFN welbekende 'tune', was een van de beste nummers van de avond" (6 Feb. 1950, p. 7)). The association with the American Forces Network radio shows how a Dutch swing number celebrating the liberation could also shape the cultural memory of the AFN radio audience in Germany without necessarily recognizing the original national background.

23 Walter van de Leur explains how critical responses continued to be present, particularly among older generations, while young people often embraced American jazz. See in this context the contribution by van de Leur in this volume.

24 A revealing case in point is the article in the Gelderlander newspaper from 12 October 1946, on the new film Follies Girls in the Scala theater. The kind of jazz music and dancing is described as an attack on "our good taste" ("aanslagen op onzen goeden smaak" (2)). Another derogative term used is "Amerikaansche humbug." Though the article acknowledged the positive things that the Americans had brought with the liberation, jazz ranked among the few exceptions which the Dutch allegedly could do without: "De nieuwe wereld bracht ons onvergetelijk veel goeds, maar wij menen hierom toch niet te moeten nalaten afwijzend te staan tegenover aanslagen op onze goeden smaak en beschaving" (2).

25 The information on the hit tune of The Ramblers is quite sparse and mentioned only in passing in Bulterman's The Ramblers Story (1973) and Co de Klete and Gabri de Wagt's Mooi Holland? De Woelige Jaren van de Ramblers (1981). 


\section{Fox-Trotting and Flirting in the Summer of 1945}

One of the most popular labels in the liberation songs referred to the foxtrot dance. This is understandable considering that foxtrot had emerged from the United States in the 1910 s from the collaboration between the innovative British dancers Vernon and Irene Castle and the leading figure in AfricanAmerican music, James Reese Europe. Allegedly, Jim Europe and Ford Dabney from the Clef Club in Harlem wrote so many songs and marches that their names were spelled backwards on some sheet music publications in order to "lend an appearance of variety" (quoted in Southern 347). After the dance craze swept over the United States in the second decade of the century, the foxtrot quickly became a transatlantic phenomenon in the 1930s. Artists from the United States were traveling across Europe; foxtrot music was the singing and dancing sensation of the inter-war years, sold via records, sheet music, and broadcast on radios. European composers embraced the format and created songs for their respective national audiences. In the 1940s, Dutch composers drew on a rich history and experience of foxtrot music in the preceding decade in order to express humor and joy about the feeling of being free again.

Many of the songs breathe the exciting atmosphere of intercultural encounters between Dutch people and the Allied forces from Canada, the UK, and the United States. In a lighthearted manner they make fun of cultural misunderstandings or language problems. Examples include Jack Millar's White Stripes in a Sky of Blue, dedicated to the Allied Air Forces "who in cause of freedom, flew over Holland," or Jack Bulterman's foxtrot Snoezepoes, in which an Allied soldier addresses every stereotype conceivable about romantic encounters with a Dutch girl on a bench: sitting "by the old Dutch mill," holding hands, whispering words of love under a linden tree, wearing wooden shoes. Alas, neither of them understood a single sentence the other spoke. The only word the soldier learned and remembers lovingly is the Dutch expression for sweetheart"snoezepoes." Jack Bulterman, a composer as well as multitalented musician on piano, trumpet, and accordion, represents a key figure in the liberation songs genre. He built on his work for The Ramblers and translated cabaret elements to the experience of liberation between 1944 and 1945. His light and joyful songs must have struck a chord with both the Dutch citizens and the liberators. $^{26}$

26 For further reference on the role of Bulterman in The Ramblers see Jack Bulterman: The Ramblers Story (1973) and Co de Kloet's and Gabri de Wagt's Mooi Holland? De Woelige Jaren van de Ramblers (1981). 
Many liberation songs express gratitude towards the liberators in songs such as Thanks Tommies! or Sing your Song of Thanks (to the Tommies and their Tanks). Some of the most memorable songs address the romantic encounters using a humorous mix of Dutch and English lyrics in songs such as Geef mij maar 'n echt Hollandsch Meisje (I prefer a real Dutch Girl), Little Holland Girl, Mamma, zïn naam is Johnny, or Mijn Tommy uit Canada. One of the few songs that actually entered Dutch cultural memory is the song Trees heeft een Canadees.

Trees heeft een Canadees

$\mathrm{O}$, wat is dat kindje in haar sas

Trees heeft een Canadees

Samen in de "jeep" en dan: vol gas!

Al vindt zij dat Engelsch lang niet mis is,

Wil zij dolgraag weten wat een kiss is

Trees heeft een Canadees

$\mathrm{O}$, wat is dat kindje in haar sas.
Trees has got a Canadian Oh, how content the child is Trees has got a Canadian Together in the jeep and then: full throttle!

Although she thinks that English is not bad,

She really wants so to know what a kiss is

Trees has got a Canadian

Oh, how content the child is.

While Trees heeft een Canadees is comparatively well known, recorded and performed regularly, the story it tells is by no means an exception in the liberation song genre. Songs such as Snoezepoes, Da-ag, Da-ag, Da-ag How I like this way to say "Hello," (followed by the self-ironic line "Da-ag, Da-ag, Da-ag is the only word of Dutch I know" in the catchy chorus) or Weet je Wat een Zoentje is? Een Zoentje is "A Little Kiss," deal with similar issues using mixed language lyrics as a means to humorously address intercultural encounters between Allied soldiers and Dutch girls:

Weet je wat een zoentje is?

Een zoentje is "a little kiss,"

Een meisje is "a little miss."

That's all, my darling!

Hoe gaat het heet

"How do you do?"

Ik hou van jou is

"I love you."

Dat is de waarheid,

"that is true."

That's all, my darling! 
Music, flirting with Allied soldiers, and American entertainment culture formed an integral part of social life in 1945. Crucial for the success of the foxtrot were novel dances such as the Lindy Hop or the Jitterbug. ${ }^{27}$ Several Dutch sheet music songs from 1945 include more or less detailed information on dance moves, which were supposed to accompany the music. Examples include De Hi Ha Holland Dans or the so-called dance sensation from Great Britain The Chestnut Tree. One of the most memorable and impressive dances is De Sten-Gun Walk- a musical homage to the resistance fighter Pierre Zom, Jr. In his dance school, the pianist discovered a large number of British Sten guns underneath the school's dance floor after the war. Recognizing the courageous role Zom played during the occupation, Leo Friedriks (aka Fred Riks) composed a song about Sten guns and worked out an elaborate choreography for dancers to joyfully re-enact the liberation of Dutch people from their occupiers. Here, music and performance create a unifying experience of self-empowerment reflecting the special feeling of being free again in 1945 .

Holland vrij! Ieder blij.
En een het Nederlandsche Volk
Dans nu de "Sten-Gun Walk."
Hold your Sten!
Pas op je tellen!
Hold your Sten!
Tred niet versnellen!

Holland vrij! Ieder blij.

En een het Nederlandsche Volk

Hold your Sten!

Pas opjetellent

Tred niet versnellen!

\author{
Holland free! Everybody happy. \\ And all of the Dutch people \\ Now dance the "Sten Gun Walk." \\ Hold your Sten! \\ Watch your step! \\ Hold your Sten! \\ Don't walk too fast!
}

It would not take long until the light-hearted approach to intercultural encounters turned bitter sweet when more than 2000 so-called war brides embarked on ships across the Ocean in search of a better life beyond the war-torn ruins and sites of destruction in the Netherlands. ${ }^{28}$ More would follow suit to emigrate and join their sweethearts from Great Britain or the United States. Before

\footnotetext{
27 For an overview of the impact of international dances on Dutch culture, see Lutgard Mutsaers' Beat Crazy (1998). Mutsaers, however, starts with the function of dance in Dutch youth culture in the 1960s.

28 Enne Koops provided a helpful overview of Dutch emigration to North America, and traced the cultural elements of attraction between the liberation and Marshall aid. See De Dynamiek van een Emigratiecultuur (2010), in particular 104-139. Rense Havinga explained that the tone of the songs change from humorously describing the romantic encounters between liberators and Dutch women towards warning and accusing the men from overseas (105).
} 
many of these songs could be recorded and enter into the collective cultural memory, the magic of 1945 was gone.

\section{Coda}

The popular sheet music on the theme of Dutch liberation and the newly won sense of freedom shows a double function of music: First, liberation songs provide the glue for Dutch citizens to create a positive emotional link to a glorious past and to imagine a proud national community. Second, the liberation songs represent a sounding memorial of gratitude to the Allied forces. Listening to liberation songs reveals a surprising dimension regarding the cultural memory of jazz and swing as the sound signature of 1945 . Before the cultural productions of records, films, and the concert tours of U.s. jazz ambassadors established American jazz as the soundtrack of liberation in retrospective view, the sheet music collection of liberation songs in Groesbeek tells a complex story of international, multilingual contact and erasure. In the Dutch cultural memory, the soundtrack of liberation is closely tied to American jazz, in particular the sounds of swing, big bands, and the close harmony singing of the Andrews Sisters. However, it was not long before African-American jazz artists such as Lionel Hampton, Art Blakey, Miles Davis, Gerry Mulligan, Max Roach, and the Modern Jazz Quartet caused a storm of enthusiasm in Amsterdam and elsewhere. In hindsight, these revolutionary performanceswhich in the case of Hampton's performance of songs such as Hey! Ba Ba Re Bop in the Amsterdam Concert Hall in September 1954 caused a riot and destruction - overlap with the memory of a "second American liberation," the wave of A-Wop-Bop-A-Loo-Bop A-Lop Bam Boom of Little Richard and Elvis Presley. ${ }^{29}$

The analysis of liberation sheet music shows that media play a crucial role in the way we remember historical events. Foxtrot songs such as Ik kan niet swingen, Mijn Tommy uit Canada, marching songs, hymns, and love songs express the desire to embrace the new international forms of expression that swept

29 A recent exhibition in the Nederlands Openluchtmuseum entitled De Amerikaanse Droom in Nederland 1944-1969 is a good case in point. The American Dream, as the organizers explain, offered exactly what the Dutch were longing for: a culture of abundance, comfort, and fun. If there were warning signs on the horizon, they were not identified as geostrategic strategies of control and smart power (in the sense of Joseph Nye combining military power with cultural diplomacy), but rather by references to stereotypes regarding an all too material surface culture. 
into the country with the Allied forces. They also helped to create a new bridge to the time before the occupation. Learning how to swing American style and marching at the same time to the rhythms of the past define the magical spirit of the summer of 1945 .

Liberation songs consist of more elements than sounds, melodies, harmonies, and lyrics. They are also part of rituals expressing emotions such as joy, pride, and hope for a better future. The cultural matrix of the European Recovery Program (better known as the Marshall Plan), the presence of AfricanAmerican musicians, and the availability of the latest jazz records during the years of reconstruction linked the soundtrack of liberation firmly to the memory of American music. Since jazz grew out of a culture of suffering and oppression, and overcame different forms of stigmatization as primitive or even degenerate towards its global victory in popular culture, it had the greatest potential to become in the words of Reinhold Wagnleitner "a model of liberation." ${ }^{30}$

Let me return to my original question: why are only a few songs such as Trees heeft een Canadees, Als Op Het Leidscheplein de Lichtjes weer eens Branden Gaan, or Lili Marleen remembered, while the majority of liberation songs such as Vrij is Nederland, v-e Day, Herrijzend Nederland, Da-ag, Da-ag, Da-ag How I like this way to say "Hello," Rotterdam Ahoy, Little Holland Girl, Eens zal de Wereld Zingen, Rood Wit Blauw, The Tommy Song, Tulips Bloom in Holland Once Again, Weet je Wat een Zoentje is? Een Zoentje is "A Little Kiss," or De "Sten-Gun Walk" - have disappeared from cultural memory? One of the reasons for the continuing popularity of some songs is the fact that they were recorded by artists such as Albert de Booij, Willy Walden, Lale Anderson, or Marlene Dietrich. In addition, having access to new recordings during and immediately after the war remained problematic due to a lack of financial means and wartime shortages of shellac. This made recording, at least of phonograph records that could be sold, close to impossible. Unless a song was featured on a radio program or in a show that was transcribed, no concurrent recorded version would exist. While analog audio recorders date back to the war years, it is highly unlikely that many were in private hands. ${ }^{31}$ As far as the rediscovery of more than 300 sheet songs is concerned, a pattern in the connection of media and memory becomes apparent: songs that are not recorded hardly ever enter into cultural memory and are easily forgotten.

30 See in this context Wagnleitner, "Jazz-The Classical Music of Globalization" (29).

31 In personal conversations and email exchange, Hugo Keesing offered inspiring suggestions and comments regarding the media situation in 1945 . 
In the magical summer of 1945 , music offered an important means to make sense of the liberation. Imaginations of the past and future form the basis for the dream of a new beginning. In the shift from socio-cultural and political destabilization towards a new national order, music provided an important emotional sense of harmony, orientation, and ordinariness. During the economic recovery and with the persuasive cultural program of the Marshall Plan with its promise "you, too, can be like us," ${ }^{32}$ American music quickly took over the role of providing the soundtrack for a new post-war generation.

\section{Bibliography}

Anonymous. De Gelderlander, 5 May 1945, 1.

Assmann, Aleida. 2011. Cultural Memory and Western Civilization: Functions, Media, Archives. Cambridge: Cambridge University Press.

Attali, Jacques. 1985. Noise. The Political Economy of Music. Translation by Brian Massumi. Minneapolis: University of Minnesota.

Bergmeier, Horst J.P. and Rainer E. Lotz. 1997. Hitler's Airwaves: The Inside Story of Nazi Radio Broadcasting and Propaganda Swing. Princeton: Yale University Press.

Bolter, Jay David and Richard Grusin. 200o. Remediation. Understanding New Media. Cambridge: The мiт Press.

Bulterman, Jack. 1973. The Ramblers Story: 38 Jaar, Máárrr ... Wij Komen Terug. Bussum: Van Holkema \& Warendorf.

Cooke, Mervyn. 2008. A History of Film Music. Cambridge: Cambridge University Press. Donkers, Jan. 2000. De Amerikaanse Droom in Nederland 1944-1969. Nijmegen: Uitgeverij sun.

Eichenauer, Richard. 1932. Musik und Rasse. München: Lehmann.

Fluck, Winfried. 2009. Romance with America? Essays on Culture, Literature, and American

Studies. Laura Bieger and Johannes Voelz (eds.). Heidelberg: Universitätsverlag Winter.

Frank, Anne. 1995. The Diary of a Young Girl. The Definitive Edition. New York: Doubleday. Groeneveld, Gerard. 2007. Zo Zong de NSB: Liedcultuur van de NSB 1931-1945. Nijmegen: Uitgeverij Vantilt.

Havinga, Rense. 2015. "De Soundtrack van de Bevrijding Tentoonstellen.” In:Soundtrack van de Bevrijding. Swingen, Zingen en Dansen op Weg Naar Vrijheid. Frank Mehring (ed.) Nijmegen: Vantilt. (102-108).

$3^{2}$ See in this context Frank Mehring, "You too can be like us! Friendly Persuasion, SelfAmericanization, and the Utopia of a New Europe." Selling Democracy / Friendly Persuasion. Rainer Rother (ed.). Berlin: DHM, 2006. (35-46). 
Heister, Hanns-Werner. 1997. "Politische Musik." MGG (Die Musik in Geschichte und Gegenwart). Volume 7·(1661-1682).

Hornung, Alfred and Rüdiger Kunow. 2002. "Preface to GlobalFictions." Amerikastudien/ American Studies. 47.2, 193-98.

Jacobs, Annelies. 2014. Het Geluid van Gisteren. Waarom Amsterdam Vroeger Ook Niet Stil Was. Maastricht: Universitaire Pers Maastricht.

Jacobs, Annelies and Karin Bijsterveld. 2013. "Der Klang der Besatzungszeit:Amsterdam 1940 bis 1945." In: Sound des Jahrhunderts. Geräusche, Töne, Stimmen 1889 bis Heute. Eds. Gerhard Paul and Ralph Schock. Bonn: Bundeszentrale für politische Bildung. (252-257).

Kaufman, Gerhard. 1997. Orgel und Nationalsozialismus. Die ideologische Vereinnahmung des Instrumentes im "Dritten Reich." Kleinblittersdorf: Musikwissenschaftliche Verlagsgesellschaft.

Keesing, Hugo. 1972. "Youth in Transition: A Content Analysis of Two Decades of Popular Music." Diss. Adelphi University.

Kloet, Co de and Gabri de Wagt. 1981. Mooi Holland? De Woelige Jaren van de Ramblers. Nieuwkoop: Heuff.

Koopes, Enne. De Dynamiek van een Emigratiecultuur. De emigratie van gereformeerden, hervormden en katholieken naar Noord-Amerika in vergelijkend perspectief (19471963). Hilversum: Uitgeverij Verloren, 2010.

Lange, Horst H. 1966. Jazz in Deutschland. Die deutsche Jazz-Chronik 19oo-1966. Berlin: Olms.

Mehring, Frank. 2003. Sphere Melodies. Die Manifestation Transzendentalistischer Ideen in der Musik von Charles Ives und John Cage. Stuttgart: Metzler.

Mehring, Frank. 2015. Soundtrack van de Bevrijding. Swingen, Zingen en Dansen op Weg Naar Vrijheid. Nijmegen: Vantilt.

Mehring, Frank. "You too can be like us! Friendly Persuasion, Self-Americanization, and the Utopia of a New Europe." Selling Democracy / Friendly Persuasion. Rainer Rother (ed.). Berlin: DHM, 2006. (35-46).

Mitry, Jean. 1997. The Aesthetics and Psychology of the Cinema. Bloomington: Indiana University Press.

Morley, Patrick. 2001. "This is the American Forces Network": The Anglo-American Battle of the Air Waves in World War II. Westport and London: Praeger.

Mutsaers, Lutgard. 1998. Beat Crazy. Een Pophistorisch Onderzoeknaar de Impactvan de Transnationale Dansrages Twist, Disco en House in Nederland. Utrecht: EML Books.

Phleps, Thomas. 2002. "Musik und Ideologie." In: Musikpsychologie. Ein Handbuch. Fourth Edition. Herbert Bruhn etal. (eds.). Reinbek: Rowohlt Taschenbuch. (94-103). Polster, Bernd (ed.). 1989. Swing Heil! Jazz im Nationalsozialismus. Berlin.

Raussert, Wilfried and James Miller Jones (eds.). 2008. Travelling Sounds. Music, Migration, and Identity in the U.S. and Beyond. Berlin: LIT Verlag. 
Schafer, R. Murray. 1986. The Thinking Ear: Complete Writings on Music Education. Toronto: Arcana Editions.

Sierp, Aline. 2014. "Integrating Europe, Integrating Memories: The Eu's Politics of Memory since 1945." In: The Transcultural Turn: Interrogating Memory Between and Beyond Borders. Lucy Bond and Jessica Rapson (eds.). Berlin: De Gruyter. (103-118).

Southern, Eileen. 1997. The Music of Black Americans. A History. Third edition. New York and London: Norton \& Company.

Swart, Aat. 1959. "Popular and Light Music." In: Music in Holland. A Review of Contemporary Music in the Netherlands. Eduard Reeser (ed.). Amsterdam: J. M. Meulenhoff. (223-235).

Uricchio, William. 2014. "Things to Come in the American Studies-Media Studies Relationship." In: American Studies Today. New Research Agendas. Eds. Winfried Fluck, Erik Redling, Sabine Sielke, Hubert Zapf. Heidelberg: Universitätsverlag Winter. $(363-382)$.

Van de Leur, Walter. 2012. “'Pure Jazz' and 'Charlatanry': A History of De Jazzwereld Magazine, 1931-1940." Dan Morgenstern Festschrift. Current Research in Jazz (www .crj-online.org), Vol. 4 .

Wagnleitner, Reinhold. 1994. Coca-Colonization and the Cold War: The Cultural Mission of the United States in Austria after the Second World War. Chapel Hill: University of North Carolina Press.

Wagnleitner, Reinhold. 2008. "Jazz-The Classical Music of Globalization." Travelling Sounds. Music, Migration, and Identity in the U.s. and Beyond. Wilfried Raussert and James Miller Jones (eds.). Berlin: LIT Verlag. (23-6o).

Wouters, Kees. 20og. "The Introduction of Jazz in The Netherlands." In: Four Centuries of Dutch-American Relations 16o9-20o9. Hans Krabbendam, Cornelis A. van Minnen, Giles Scott-Smith (eds.). Amsterdam: Boom. (497-508).

\section{Liberation Songs}

Als Op Het Leidscheplein de Lichtjes weer eens Branden Gaan. Words by Bert van Eijck, Music by Cor Steyn. G.J. van Zuylen, 1943.

Bells Now Ring Again, The. Words and Music by Ar Colijn. A.v.d. Kleyn, 1945.

Bouncin' in Bavaria. Music by Jack Bulterman. Ch. Bens, 1948.

Da-ag, Da-ag, Da-ag (How I like this way to say "Hello"). Words and Music by Jack Bulterman. G.J. van Zuylen, 1945.

Eens zal de Wereld Zingen. Words by Han Dunk, Music by A.v.d. Ouderaa. C.W.H. Snoek, circa 1940.

Gee, I like this Boogey Woogey Swing. Words by Bart Ekker, Music by Han Ninaber. Roniepress, 1945 . 
Geef mij maar 'n echt Hollandsch Meisje. Words by Fred Fagel and Wim de Vries, Music by Fred Fagel, 1945 .

Herrijzend Nederland. Words by Anton Beuving, Music by Tom Erich. B.H. Smit, 1945 . Hi Ha Holland Dans. De, Words and Music by Jaap de Bie. Metro Music Company, 1939. Ik kan niet swingen. Words by Bob Wallagh, Music by Fredy Salten. Basart, 1946.

Lili Marleen, (Onder De Lantaren), Dutch Words by Arn. Frank, Music by N. Schultze. Gramac, 1939.

Little Holland Girl. Words and Music by Dutchie. Luctor, 1945.

Mamma, zijn naam is Johnny. Words and Music by Ar Colijn. A. v.d. Kleyn, 1945.

Mijn Tommy uit Canada. Words by Josef Baar, Music by Joop de Leur and Francis Bay. B.H. Smit, 1945 .

“Sten-Gun Walk” De. Words by Daan Hooijkaas, Music by L. Fred Riks. C.W.H. Snoek, 1945 .

Rood, Wit, Blauw. Music by Willy Schootemeyer. Hollanda, circa 1939.

Rotterdam Ahoy. Words by Paul Duval, Music by Hans Ninaber. Edition Cosmopolite, 1945 .

Snoezepoes. Words and Music by Jack Bulterman. Muziek "Smith," 1940.

Tommy Song, The. Words and Music by Kees Sommer. J.A.H. Wagenaar, 1945.

Trees heeft een Canadees. Words by Lou de Groot, Music by Albert de Booij Roniepers, 1945.

Tulips Bloom in Holland Once Again. Words and Music by William C. Blees. Dekeling \& Swart, 1945 .

Vrij is Nederland, (Jubelend Nederland \#3). Words by Dico van der Meer, Music by Piet Lustenhouwer Firma P. van Belkum Az., 1945.

Vrijheidsmars, De. Words and Music by H.J. van Amersvoort. Muziekhandel H.J. van Amersvoort, ca. 1944.

Vry Nederland (Vryheidsmarsch). Words by Jan van Klooster, Music by Brucht van Klooster. Druk de Bussy, 1945.

We zijn weer Holland en we zijn weer vrij! Words and Music by Herman Stenz. G. Alsbach \& Co., 1945 .

Weet je Wat een Zoentje is? Een Zoentje is “A Little Kiss." Words and Music by Herbert Nelson. Metro Muziek, 1946.

White Stripes in a Sky of Blue. Words and Music by Jack Millar and Han Dunk. Metro Muziek, 1945

Wij zijn weer vrij! (Lied van Vrijheid en Vrede). Words \& Music by Herman Stenz. G. Alsbach \& Co., 1945 . 